\title{
Reactivity of RhCp* Complexes Containing Labile Ligands toward Potential Linking Ligands Containing Terminal Thiophene or Furan Rings: Preparation and Structures of $\left[\mathrm{Cp} * \mathrm{Rh}\left(\mathrm{L}^{1}\right) \mathrm{Cl}_{2}\right],\left[\mathrm{Cp} * \mathrm{Rh}\left(\eta^{2}-\mathrm{NO}_{3}\right)\left(\mathrm{L}^{1}\right)\right](\mathrm{OTf})$, and $\left\{\left[\operatorname{Rh}\left(L^{2}\right)\right] \cdot(\mathrm{OTf})\right\}_{\infty}\left[\mathrm{L}^{1}=1,2-\mathrm{Bis}((\right.$ thiophen-2-yl)methylene)hydrazine $)$; $\mathbf{L}^{2}=1,2-\operatorname{Bis}(($ furan-2-yl)methylene)hydrazine]
}

\author{
Kyung-Eun Lee and Soon W. Lee* \\ Department of Chemistry (BK21), Sungkyunkwan University, Natural Science Campus, Suwon 440-746, Korea \\ *E-mail: soonwlee@skku.edu \\ Received August 22, 2010, Accepted September 28, 2010
}

\begin{abstract}
Rhodium(III)-Cp* complexes containing labile ligands, $\left[\mathrm{Cp} * \mathrm{RhCl}_{2}\right]_{2},\left[\mathrm{Cp} * \mathrm{Rh}\left(\eta^{2}-\mathrm{NO}_{3}\right)(\mathrm{OTf})\right]$, and $\left[\mathrm{Cp} * \mathrm{Rh}(\mathrm{OH})_{3}\right](\mathrm{OTf})_{2}$, reacted with potential linking ligands $\left[\mathrm{L}^{1}=(2\right.$-thiophene $)-\mathrm{CH}=\mathrm{N}-\mathrm{N}=\mathrm{CH}-(2$-thiophene $) ; \mathrm{L}^{2}=(2$-furan $)-\mathrm{CH}=\mathrm{N}-\mathrm{N}=\mathrm{CH}-$ (2-furan)] to give two molecular compounds, $\left[\mathrm{Cp} * \mathrm{Rh}\left(\mathrm{L}^{1}\right) \mathrm{Cl}_{2}\right](\mathbf{1})$ and $\left[\mathrm{Cp} * \mathrm{Rh}\left(\eta^{2}-\mathrm{NO}_{3}\right)\left(\mathrm{L}^{1}\right)\right](\mathrm{OTf}) \cdot \mathrm{CH}_{2} \mathrm{Cl}_{2}\left(\mathbf{2} \cdot \mathrm{CH}_{2} \mathrm{Cl}_{2}\right)$, and one 1-dimensioanl coordination polymer, $\left\{\left[\mathrm{Rh}\left(\mathrm{L}^{2}\right)\right] \cdot(\mathrm{OTf})\right\}_{\infty}(\mathbf{3})$. Whereas one imine nitrogen atom within the ligand is coordinated to the $\mathrm{Rh}$ metal in compounds $\mathbf{1}$ and $\mathbf{2}$, both nitrogen atoms are bound to two neighboring $\mathrm{Rh}$ metals in compound 3 to lead to a 1-D chain polymer.
\end{abstract}

Key Words: Rhodium-Cp*, Bis(thipohene), Bis(furan), 1-D Chain, Rhodium coordination polymer

\section{Introduction}

Linking ligands containing terminal pyridyl or carboxylate groups are known to react with metal complexes to form intriguing macromolecules and supramolecules. For example, many group 10 metal (especially, Pd and Pt) complexes react with such ligands to form a variety of supramolecules with geometries ranging from a triangle to a polygon or polyhedron. ${ }^{1-4}$ In particular, several pseudo-octahedral Rh-Cp* $\left(\mathrm{Cp}^{*}=\mathrm{C}_{5} \mathrm{Me}_{5}\right)$ complexes produced molecular species, dimers, or polygons when treated with tailored ligands, depending on the nature of the used ligands. ${ }^{5-15}$ For instance, Yamamoto and co-workers reported on the formation molecular species from the reactions of isocyanoazobenzene with Rh-Cp*. ${ }^{11}$ Jin's group prepared tetranuclear rectangular Rh-Cp* complexes by employing bis(pyridine)- or dicarboxylate-type linking ligands. ${ }^{15}$

Our research group has been continually interested in the reactivity of $\mathrm{Rh}-\mathrm{Cp}^{*}$ complexes containing labile ligands such as $\mathrm{H}_{2} \mathrm{O}, \mathrm{NO}_{3}{ }^{-}$, and OTf ligands. ${ }^{16-19}$ For example, discrete rectangles, dinuclear rods, and a 1-dimensional network were prepared from the Rh-Cp* complexes $\left\{\left[\mathrm{Cp} * \mathrm{Rh}\left(\eta^{1}-\mathrm{NO}_{3}\right)\left(\eta^{2}-\right.\right.\right.$ $\left.\left.\mathrm{NO}_{3}\right)\right]$ and $\left.\left.\left[\mathrm{Cp} * \mathrm{Rh}\left(\mathrm{H}_{2} \mathrm{O}\right)_{3}\right](\mathrm{OTf})_{2}\right]\right\}$ and bis(pyridine)-type linking ligands. ${ }^{17}$ In these products, the terminal pyridyl $\mathrm{N}$ atoms are coordinated to the $\mathrm{Rh}$ metal, but coordination polymers were not formed.

As an extension of our study, we investigated the reactivity of the Rh-Cp* complexes, $\left[\mathrm{Cp} * \mathrm{RhCl}_{2}\right]_{2},\left[\mathrm{Cp} * \mathrm{Rh}\left(\eta^{2}-\mathrm{NO}_{3}\right)\right.$ (OTf)], and $\left[\mathrm{Cp}^{*} \mathrm{Rh}\left(\mathrm{OH}_{2}\right)_{3}\right](\mathrm{OTf})_{2}$, toward potential linking ligands $\left[\mathbf{L}^{\mathbf{1}}=1,2\right.$-bis( (thiophen-2-yl)methylene)hydrazine; $\mathbf{L}^{\mathbf{2}}=$ 1,2-bis((furan-2-yl)methylene)hydrazine] that contain terminal thiophene $\left(\mathbf{L}^{\mathbf{1}}\right)$ or furan rings $\left(\mathbf{L}^{\mathbf{2}}\right)$. We herein report the preparation and structures of two molecular species, $\left[\mathrm{Cp}^{*} \mathrm{Rh}\left(\mathbf{L}^{\mathbf{1}}\right)\right.$ $\left.\mathrm{Cl}_{2}\right](\mathbf{1})$ and $\left[\mathrm{Cp} * \mathrm{Rh}\left(\eta^{2}-\mathrm{NO}_{3}\right)\left(\mathbf{L}^{\mathbf{1}}\right)\right](\mathrm{OTf}) \cdot \mathrm{CH}_{2} \mathrm{Cl}_{2}\left(\mathbf{2} \cdot \mathrm{CH}_{2} \mathrm{Cl}_{2}\right)$, together with one 1-D rhodium coordination polymer $\left[\mathrm{Rh}\left(\mathbf{L}^{2}\right)\right]$ (OTf) (3).

\section{Experimental Section}

All air-sensitive compounds were manipulated under argon by standard Schlenk-line techniques. Solvents were vacuumdistilled and stored under argon. All reactions were performed at room temperature. Starting compounds $\left[\mathrm{Cp} * \mathrm{RhCl}_{2}\right]_{2},{ }^{20}[\mathrm{Cp} * \mathrm{Rh}$ $\left.\left(\eta^{2}-\mathrm{NO}_{3}\right)(\mathrm{OTf})\right](\mathrm{OTf}=$ trifluoromethane sulfonate $),{ }^{21}[\mathrm{Cp} * \mathrm{Rh}$ $\left.\left(\mathrm{OH}_{2}\right)_{3}\right](\mathrm{OTf})_{2},{ }^{22} \mathbf{L}^{1}{ }^{23}$ and $\mathbf{L}^{2}$ were prepared by the literature methods. ${ }^{24} \mathrm{H}$ and ${ }^{13} \mathrm{C}\left\{{ }^{1} \mathrm{H}\right\}$ NMR spectra were obtained on an $500 \mathrm{MHz}$ Varian Inova spectrometer at the Cooperative Center for Research Facilities (CCRF) in Sungkyunkwan University. IR spectra were recorded with a Nicolet 320 FT IR spectrophotometer. The analytical laboratories at Basic Science Institute of Kangneung-Won Ju National University carried out elemental analyses of the products.

Preparation of $\left[\mathbf{C p} * \mathbf{R h}\left(\mathbf{L}^{\mathbf{1}}\right) \mathbf{C l}_{\mathbf{2}}\right]$ (1). To a Schlenk flask containing $\left[\mathrm{Cp}^{*} \mathrm{RhCl}_{2}\right]_{2}(110 \mathrm{mg}, 0.178 \mathrm{mmol})$ were added $\mathrm{MeOH}$ $(20 \mathrm{~mL})$ and $\mathbf{L}^{1}$ (40 mg, $\left.0.182 \mathrm{mmol}\right)$. After the solution was stirred for $12 \mathrm{~h}$, the solvent was removed, and the resulting residue was washed with diethyl ether $(10 \mathrm{~mL} \times 2)$ to give red solids. Recrystallization from $\mathrm{MeOH}-\mathrm{Et}_{2} \mathrm{O}$ gave red crystals of [Cp*Rh( $\left.\left.\mathbf{L}^{1}\right) \mathrm{Cl}_{2}\right](\mathbf{1}, 133 \mathrm{mg}, 0.251 \mathrm{mmol}, 70 \%$ yield $) . \mathrm{mp}$ (dec) 133 - $135{ }^{\circ} \mathrm{C} .{ }^{1} \mathrm{H}$ NMR $\left(\mathrm{CDCl}_{3}, \delta\right) 8.77(\mathrm{~s}, 2 \mathrm{H}), 7.48-7.42(\mathrm{~m}$, $4 \mathrm{H}), 7.13-7.11(\mathrm{~m}, 2 \mathrm{H}), 1.63(\mathrm{~s}, 15 \mathrm{H}) .{ }^{13} \mathrm{C}\left\{{ }^{1} \mathrm{H}\right\} \mathrm{NMR}(125$ $\left.\mathrm{MHz}, \mathrm{CDCl}_{3}, \delta\right) 156.0,139.3,132.6,130.2,128.0,9.6$. IR (KBr, $\left.\mathrm{cm}^{-1}\right) 3513(\mathrm{w}), 3073(\mathrm{w}), 2911(\mathrm{w}), 2353(\mathrm{w}), 1818(\mathrm{w}), 1670$ (w), 1598 (s), 1417 (m), 1215 (m), 1024 (m), 949 (m), 846 (m),

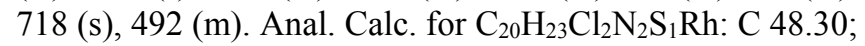
H 4.66; N 5.63. Found: 47.89; H 4.19; N 4.92.

Preparation of $\left[\mathbf{C p} * \mathbf{R h}\left(\eta^{2}-\mathrm{NO}_{3}\right)\left(\mathrm{L}^{1}\right)\right](\mathrm{OTf}) \cdot \mathbf{C H}_{2} \mathrm{Cl}_{\mathbf{2}}\left(\mathbf{2} \cdot \mathbf{C H}_{2}\right.$ $\left.\mathbf{C l}_{2}\right) \cdot\left[\mathrm{Cp} * \mathrm{Rh}\left(\eta^{2}-\mathrm{NO}_{3}\right)(\mathrm{OTf})\right](200 \mathrm{mg}, 0.445 \mathrm{mmol})$ and $\mathbf{L}^{\mathbf{1}}(98$ $\mathrm{mg}, 0.445 \mathrm{mmol})$ were added to $\mathrm{CH}_{2} \mathrm{Cl}_{2}(10 \mathrm{~mL})$ in a Schlenk flask. The solution was stirred for $15 \mathrm{~h}$ and then concentrated under reduced pressure to two-thirds of its original volume. The resulting solution was filtered and then layered with diethyl 
Table 1. X-ray data collection and structure refinement

\begin{tabular}{|c|c|c|c|}
\hline Compound & 1 & 2. $\mathrm{CH}_{2} \mathrm{Cl}_{2}$ & 3 \\
\hline Empirical formula & $\mathrm{C}_{20} \mathrm{H}_{23} \mathrm{Cl}_{2} \mathrm{~N}_{2} \mathrm{RhS}_{2}$ & $\mathrm{C}_{22} \mathrm{H}_{23} \mathrm{Cl}_{2} \mathrm{~F}_{3} \mathrm{~N}_{3} \mathrm{O}_{6} \mathrm{RhS}_{3}$ & $\mathrm{C}_{11} \mathrm{H}_{8} \mathrm{~F}_{3} \mathrm{~N}_{2} \mathrm{O}_{5} \mathrm{RhS}$ \\
\hline Formula weight & 529.33 & 752.42 & 440.16 \\
\hline Temperature, $\mathrm{K}$ & $296(2)$ & $296(2)$ & $296(2)$ \\
\hline Crystal system & orthorhombic & monoclinic & triclinic \\
\hline Space group & $P 2_{1} 2_{1} 2_{1}$ & $P 2_{1}$ & $P-1$ \\
\hline$a, \AA$ & $7.6206(2)$ & $9.1143(4)$ & $8.3198(10)$ \\
\hline$b, \AA$ & $16.626(5)$ & $13.819(6)$ & $9.2076(2)$ \\
\hline$c, \AA$ & $17.370(5)$ & $12.123(6)$ & $11.6871(2)$ \\
\hline$\alpha, \operatorname{deg}$ & & & $74.066(1)$ \\
\hline$\beta, \operatorname{deg}$ & & $93.132(3)$ & $70.626(1)$ \\
\hline$\gamma$, deg & & & $73.980(1)$ \\
\hline$V, \AA^{3}$ & $2200.9(1)$ & $1524.6(1)$ & $795.10(2)$ \\
\hline Z & 4 & 2 & 2 \\
\hline$d_{\text {cal }}, \mathrm{g} \mathrm{cm}^{-3}$ & 1.598 & 1.639 & 1.839 \\
\hline$\mu, \mathrm{mm}^{-1}$ & 1.217 & 0.999 & 1.260 \\
\hline$F(000)$ & 1072 & 756 & 432 \\
\hline$T_{\max }$ & 0.8199 & 0.8485 & 0.9059 \\
\hline$T_{\min }$ & 0.6969 & 0.6564 & 0.6326 \\
\hline$\theta$ range $\left(^{\circ}\right)$ & $1.70-28.45$ & $1.68-28.39$ & $1.89-28.36$ \\
\hline No. of reflections measured & 35462 & 30896 & 21706 \\
\hline No. of reflections unique & 5511 & 7096 & 3885 \\
\hline No. of reflections with $I>2 \sigma(I)$ & 4694 & 5402 & 2986 \\
\hline No. of parameters refined & 249 & 367 & 240 \\
\hline Max., in $\Delta \rho\left(\mathrm{e} \AA^{-3}\right)$ & 0.987 & 0.733 & 0.767 \\
\hline Min., in $\Delta \rho\left(\mathrm{e} \AA^{-3}\right)$ & -0.735 & -0.422 & -0.511 \\
\hline$G O F$ on $F^{2}$ & 1.050 & 1.016 & 1.055 \\
\hline$R_{1}^{a}$ & 0.0428 & 0.0407 & 0.0402 \\
\hline$w R_{2}^{b}$ & 0.0866 & 0.0943 & 0.0897 \\
\hline
\end{tabular}

${ }^{a} R_{1}=\Sigma\left\|F_{o}|-| F\right\| / \Sigma\left|F_{\mathrm{o}}\right|,{ }^{b} w R_{2}=\Sigma\left[w\left(F_{o}{ }^{2}-F_{c}{ }^{2}\right)^{2}\right] / \Sigma\left[w\left(F_{o}{ }^{2}\right)^{2}\right]^{1 / 2}$

Table 2. Selected bond lengths $(\AA)$ and bond angles $\left({ }^{\circ}\right)$

\begin{tabular}{|c|c|c|c|c|c|}
\hline $\begin{array}{l}\text { Compound } 1 \\
\text { Rh1-N1 } \\
\text { C15-N1-N2 } \\
\text { N2-C16-C17 }\end{array}$ & $\begin{array}{l}2.184(4) \\
106.8(4) \\
118.4(4)\end{array}$ & $\begin{array}{l}\text { Rh1-C11 } \\
\text { N1-N2-C16 }\end{array}$ & $\begin{array}{l}2.4047(15) \\
113.5(4)\end{array}$ & $\begin{array}{l}\text { Rh1-Cl2 } \\
\text { N1-C15-C14 }\end{array}$ & $\begin{array}{l}2.4233(14) \\
134.7(6)\end{array}$ \\
\hline $\begin{array}{l}\text { Compound } 2 \cdot \mathrm{CH}_{2} \mathrm{Cl}_{2} \\
\text { Rh1-N1 } \\
\text { N1-N2 } \\
\text { C15-N1-N2 } \\
\text { N2-C16-C17 }\end{array}$ & $\begin{array}{l}2.125(4) \\
1.403(5) \\
111.6(4) \\
119.1(4)\end{array}$ & $\begin{array}{l}\text { Rh1-O1 } \\
\text { N1-C15 } \\
\text { C16-N2-N1 }\end{array}$ & $\begin{array}{l}2.174(3) \\
1.297(6) \\
114.8(4)\end{array}$ & $\begin{array}{l}\text { Rh1-O2 } \\
\text { N2-C16 } \\
\text { N1-C15-C14 }\end{array}$ & $\begin{array}{l}2.192(4) \\
1.301(6) \\
130.1(4)\end{array}$ \\
\hline $\begin{array}{l}\text { Compound } 3 \\
\text { Rh1-N1 } \\
\text { Rh1-O2 } \\
\text { N1-Rh1-N2 }\end{array}$ & $\begin{array}{l}2.294(3) \\
2.736(3) \\
137.78(9)\end{array}$ & $\begin{array}{l}\text { Rh1-N2 } \\
\text { Rh1-O3 } \\
\text { N1- Rh1-O3 }\end{array}$ & $\begin{array}{l}2.317(2) \\
2.527(4) \\
89.83(12)\end{array}$ & $\begin{array}{l}\text { Rh1-O1 } \\
\text { Rh1-O5\#1 } \\
\text { C5-N1-Rh1\#2 }\end{array}$ & $\begin{array}{l}2.887(3) \\
2.731(4) \\
76.78(18)\end{array}$ \\
\hline
\end{tabular}

Symmetry transformations used to generate equivalent atoms: $\# 1=-x+1,-y+2,-z+2 ; \# 2=-x,-y+2 ;-z+2$.

ether. After three days, orange crystals formed, which were filtered and washed with $n$-hexane $(5 \mathrm{~mL} \times 2)$ to give [Cp*Rh $\left.\left(\eta^{2}-\mathrm{NO}_{3}\right)\left(\mathbf{L}^{1}\right)\right](\mathrm{OTf}) \cdot \mathrm{CH}_{2} \mathrm{Cl}_{2}\left(\mathbf{2} \cdot \mathrm{CH}_{2} \mathrm{Cl}_{2}, 271 \mathrm{mg}, 0.360 \mathrm{mmol}\right.$, $81 \%$ yield). mp (dec) $126-128^{\circ} \mathrm{C} .{ }^{1} \mathrm{H}$ NMR $\left(\mathrm{CDCl}_{3}, \delta\right) 8.77$ (s, $1 \mathrm{H}), 8.34$ (s, $1 \mathrm{H}), 7.91(\mathrm{~s}, 1 \mathrm{H}), 7.84(\mathrm{~s}, 1 \mathrm{H}), 7.72(\mathrm{~s}, 2 \mathrm{H})$, 7.23-7.18 (m, $2 \mathrm{H}), 1.63(\mathrm{~s}, 15 \mathrm{H}) .{ }^{13} \mathrm{C}\left\{{ }^{1} \mathrm{H}\right\} \mathrm{NMR}(125 \mathrm{MHz}$, $\left.\mathrm{CDCl}_{3}, \delta\right) 156.4,140.6,136.5,134.1,133.2,129.1,128.2,97.1$, 9.6. IR (KBr, cm $\left.{ }^{-1}\right): 3873(\mathrm{w}), 3663(\mathrm{w}), 2622(\mathrm{w}), 2358(\mathrm{~m})$, 2069 (w), 1597 (s), 1518 (s), 1418 (w), 1376 (w), 1270 (s), 1149 (m), $1022(\mathrm{~m}), 945(\mathrm{w}), 754(\mathrm{w}), 717(\mathrm{~s}), 633(\mathrm{~s}), 557(\mathrm{~m}), 505$ (m), 418 (m), 403 (s). Anal. Calc. for $\mathrm{C}_{22} \mathrm{H}_{23} \mathrm{Cl}_{2} \mathrm{~F}_{3} \mathrm{~N}_{3} \mathrm{O}_{6} \mathrm{RhS}_{3}$ : C 35.12; H 3.08; N 5.58. Found: C 35.80; H 2.55; N 5.34.

Preparation of $\left\{\left[\mathbf{R h}\left(\mathbf{L}^{2}\right)\right](\mathbf{O T f})\right\}_{\infty}(\mathbf{3})$. $\left[\mathrm{Cp} * \mathrm{Rh}\left(\mathrm{OH}_{2}\right)_{3}\right](\mathrm{OTf})_{2}$ (52 $\mathrm{mg}, 0.088 \mathrm{mmol}$ ) was dissolved in dichloromethane $(3 \mathrm{~mL})$, and the resulting solution was filtered. A diethyl ether solution (5 mL) containing $\mathbf{L}^{2}$ (17 $\left.\mathrm{mg}, 0.090 \mathrm{mmol}\right)$ was prepared in the same way. The $\mathrm{Et}_{2} \mathrm{O}$ solution was layered onto the top of the $\mathrm{CH}_{2} \mathrm{Cl}_{2}$ solution. After three days, the resulting colorless crystals were collected by filtration and washed with $n$-hexane $(5 \mathrm{~mL} \times$ 2) to give $\left\{\left[\mathrm{Rh}\left(\mathbf{L}^{2}\right)\right](\mathrm{OTf})\right\}_{\infty}(\mathbf{3}, 12 \mathrm{mg}, 0.027 \mathrm{mmol}, 31 \%$ yield $)$. 
$\mathrm{mp}(\mathrm{dec}) 124-126^{\circ} \mathrm{C} .{ }^{1} \mathrm{H} \mathrm{NMR}\left(\mathrm{CDCl}_{3}, \delta\right) 8.62(\mathrm{~s}, 2 \mathrm{H}), 7.82$ $(\mathrm{s}, 2 \mathrm{H}), 7.17(\mathrm{~s}, 2 \mathrm{H}), 6.71(\mathrm{~s}, 2 \mathrm{H}) .{ }^{13} \mathrm{C}\left\{{ }^{1} \mathrm{H}\right\}$ NMR $(125 \mathrm{MHz}$, acetone- $\left.d_{6}, \delta\right) 205.3,152.5,147.8,120.4,113.3$. IR $\left(\mathrm{KBr}, \mathrm{cm}^{-1}\right)$ 3453 (s), 2931 (m), 2364 (m), 2059 (m), 1640 (s), 1465 (m), 1263 (s), 1167 (m), 1027 (m), 933 (m), 812 (m), 756 (s), 630 (s), 494 (s). Anal. Calc. for $\mathrm{C}_{11} \mathrm{H}_{8} \mathrm{~F}_{3} \mathrm{~N}_{2} \mathrm{O}_{5} \mathrm{RhS}$ : C 30.02; H 1.83; N 6.36. Found: $29.66 ; \mathrm{H} 2.02 ; \mathrm{N} 6.64$.

X-ray structure detemination. X-ray data were collected with a Bruker Smart APEX2 diffractometer equipped with a Mo $\mathrm{X}$-ray tube (CCRF). Empirical absorption corrections were made for all polymers with SADABS. ${ }^{25}$ All calculations were carried out with SHELXTL programs. ${ }^{26}$ A red crystal of compound $\mathbf{1}$, shaped as a block of approximate dimensions $0.32 \times 0.24 \times 0.17$ $\mathrm{mm}^{3}$, was used for crystal- and intensity-data collection. An orange crystal of compound $2 \cdot \mathrm{CH}_{2} \mathrm{Cl}_{2}$ (a block, $0.46 \times 0.44 \times$ $0.17 \mathrm{~mm}^{3}$ ) and a colorless crystal of compound 3 (a block, $0.40 \times$ $0.10 \times 0.08 \mathrm{~mm}^{3}$ ) were used. All non-hydrogen atoms were refined anisotropically. Whereas hydrogen atoms in compounds 1 and $2 \cdot \mathrm{CH}_{2} \mathrm{Cl}_{2}$ were generated in idealized positions and refined in a riding mode, those in compound $\mathbf{3}$ could be located and refined isotropically. Table 1 shows the details on crystal data, intensity collection, and refinements. Selected bond lengths and angles are given in Table 2.

Crystallographic data for the structural analysis have been deposited at the Cambridge Crystallographic Data Center: 787167 (1), 787168 (2) and 787169 (3). Copies of this information may be obtained free of charge from: The director, CCDC, 12 Union Road, Cambridge, CB2 1EZ, UK (Fax: +44-1223336-033; email: deposit@ccdc.cam.ac.uk or www: http://www. ccdc.cam.ac.uk).

\section{Results and Discussion}

Preparation of compounds 1-3. Our initial goal in this study was to prepare rhodium coordination polymers linked by $\mathrm{Rh}-\mathrm{S}$ or Rh-O bonds. With this goal in mind, the Cl-bridged Rh(III) dimer $\left[\mathrm{Cp}^{*} \mathrm{RhCl}_{2}\right]_{2}$ was treated with a potential bis(thiophene)type linking ligand $\left(\mathbf{L}^{\mathbf{1}}\right)$, because the soft $\mathrm{Rh}$ metal is expected to prefer to coordinate to the soft $\mathrm{S}$ atoms over the hard $\mathrm{N}$ atoms within the ligand to produce a desired polymeric species. However, inconsistent with our expectation, the red crystalline product turned out to be a molecular species, $\left[\mathrm{Cp} * \mathrm{Rh}\left(\mathbf{L}^{\mathbf{1}}\right) \mathrm{Cl}_{2}\right](\mathbf{1})$, which has been formed by the Rh-N covalent bond (eq 1). In other words, the reaction in eq 1 is a cleavage of the starting compound by ligand $\mathbf{L}^{1}$.

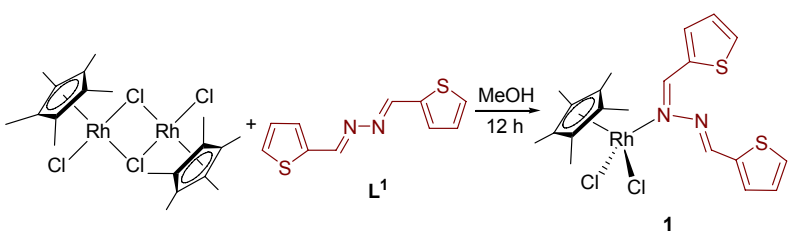

The complex $\left[\mathrm{Cp} * \mathrm{Rh}\left(\eta^{2}-\mathrm{NO}_{3}\right)(\mathrm{OTf})\right]$ previously exhibited the reactivity to mediate the cycloaddition of alkynes and alkynyl esters, due to the presence of two labile ligands $\left(\mathrm{NO}_{3}{ }^{-}\right.$and OTf $).{ }^{19}$ We expected such labile ligands to be replaced readily by other ligands, and therefore this complex was treated with ligands $\mathbf{L}^{1}$ and $\mathbf{L}^{2}$. Whereas the reaction involving $\mathbf{L}^{1}$ produced an orange crystalline product, $\left[\mathrm{Cp} * \mathrm{Rh}\left(\eta^{2}-\mathrm{NO}_{3}\right)\left(\mathbf{L}^{\mathbf{1}}\right)\right](\mathrm{OTf})$. $\mathrm{CH}_{2} \mathrm{Cl}_{2}\left(\mathbf{2} \cdot \mathrm{CH}_{2} \mathrm{Cl}_{2}\right)$ (eq 2$)$, the corresponding reaction employing $\mathbf{L}^{2}$ gave an oily product, which could not be characterized. Like compound $\mathbf{1}$, compound $\mathbf{2}$ is also a molecular species and has the Rh-N (imine) bond. Eq 2 indicates that the OTf ligand is more labile than the $\mathrm{NO}_{3}{ }^{-}$ligand in this substitution reaction. Compound $\mathbf{2}$ is somewhat moisture-sensitive and therefore should be kept in a desiccator.

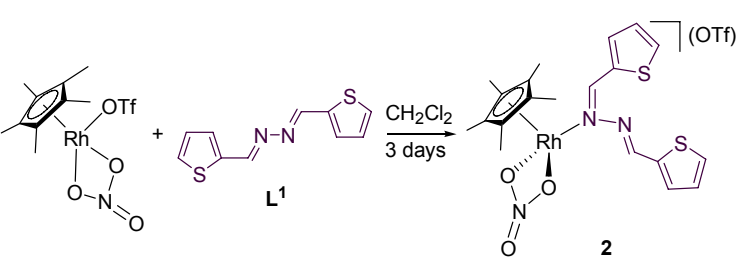

As mentioned in Introduction, we previously prepared several rectangular tetranuclear $\mathrm{Rh}$ species from the ionic $\mathrm{Cp} * \mathrm{Rh}-$ aqua complex $\left[\mathrm{Cp}^{*} \mathrm{Rh}\left(\mathrm{H}_{2} \mathrm{O}\right)_{3}\right](\mathrm{OTf})_{2}$ and bis(pyridine)-type ligands, in which the $\mathrm{Cp} * \mathrm{Rh}$ fragments were linked by the $\mathrm{Rh}-\mathrm{N}$ (pyridine) bonds. ${ }^{17}$ To extend the scope of the reactivity of $\left[\mathrm{Cp}^{*}\right.$ $\left.\mathrm{Rh}\left(\mathrm{H}_{2} \mathrm{O}\right)_{3}\right](\mathrm{OTf})_{2}$ to bis(furan)-type ligands $\left(\mathbf{L}^{2}\right)$, the reaction of $\left[\mathrm{Cp}^{*} \mathrm{Rh}\left(\mathrm{H}_{2} \mathrm{O}\right)_{3}\right](\mathrm{OTf})_{2}$ with ligand $\mathbf{L}^{2}$ was attempted. A diethyl ether solution of ligand $\mathbf{L}^{2}$ was layered onto the top of a dichloromethane solution of $\left[\mathrm{Cp}^{*} \mathrm{Rh}\left(\mathrm{H}_{2} \mathrm{O}\right)_{3}\right](\mathrm{OTf})_{2}$ to give a 1-D polymer $\left\{\left[\mathrm{Rh}\left(\mathbf{L}^{2}\right)\right](\mathrm{OTf})\right\}_{\infty}(\mathbf{3})$ instead of a rectangular species (eq 3). On the contrary, the reaction of $\left[\mathrm{Cp}^{*} \mathrm{Rh}\left(\mathrm{H}_{2} \mathrm{O}\right)_{3}\right](\mathrm{OTf})_{2}$ with $\mathbf{L}^{1}$ gave an oily product, which could not be characterized. In this reaction, the $\mathrm{Rh}$ metal was formally reduced from +3 to +1 . Compound 3 is a $1-\mathrm{D}$ polymer linked by $\mathrm{Rh}-\mathrm{N}$ (imine) bonds, not Rh-O (furan) bonds. The oxygen atoms in the terminal furan ring and the OTf counterions are strongly attracted to the Rh metal by van der Waals contacts (dotted lines in eq 3 ).

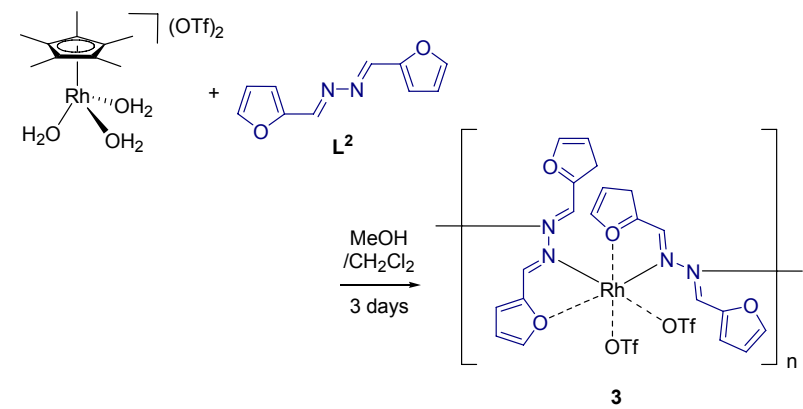

The most striking feature of this reaction (eq 3 ) is the elimination of the $\mathrm{Cp}^{*}$ ring, which is typically regarded as a very strongly coordinating, bulky spectator ligand. Consistent with our expectation, all the aqua ligands in the starting compound were replaced by two $\mathbf{L}^{2}$ ligands. In other words, this reaction is another example illustrating the highly labile character of the aqua ligands in the starting compound. ${ }^{17}$

All compounds were characterized by spectroscopy (NMR and IR), elemental analysis, and X-ray diffraction. The $\mathrm{C}=\mathrm{N}$ stretches of compounds $\mathbf{1}$ and $\mathbf{2}$ appear at 1598 and $1597 \mathrm{~cm}^{-1}$, respectively, whereas that in the free ligand $\left(\mathbf{L}^{\mathbf{1}}\right)$ appears at $1621 \mathrm{~cm}^{-1}$. $^{3}$ By contrast, compound 3 exhibits the $\mathrm{C}=\mathrm{N}$ stretch at $1640 \mathrm{~cm}^{-1}$, whereas the free $\mathbf{L}^{2}$ exhibits that at $1613 \mathrm{~cm}^{-1}{ }^{24}$ 


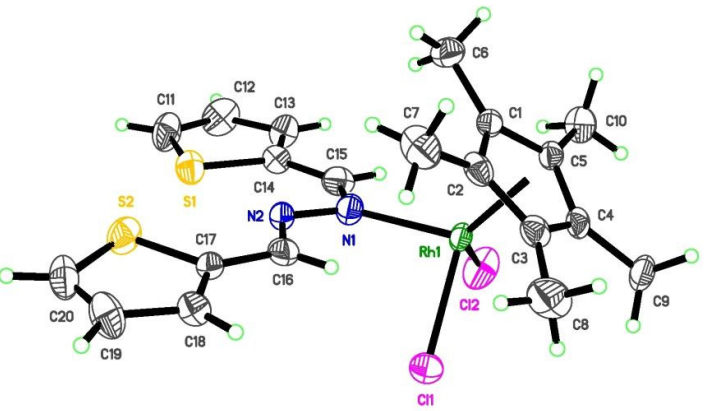

Figure 1. ORTEP drawing of compound 1.

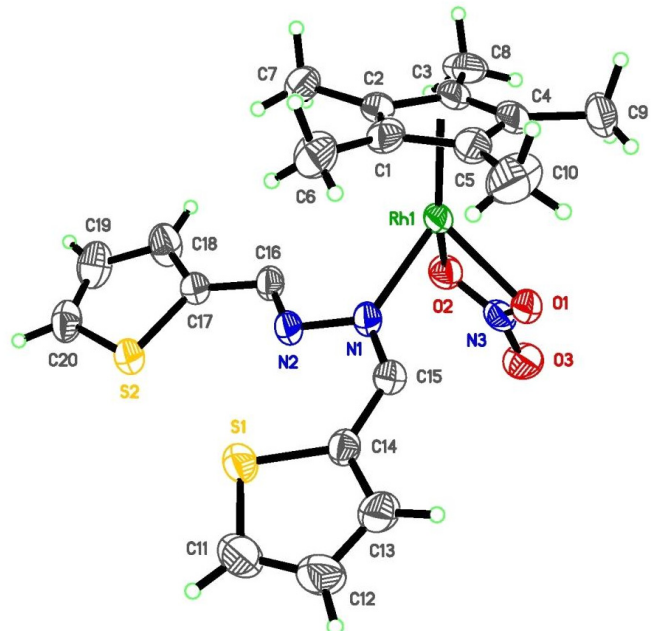

Figure 2. ORTEP drawing of the cationic part of compound $2 \cdot \mathrm{CH}_{2} \mathrm{Cl}_{2}$.

Unfortunately, we cannot provide a reasonable argument for the up-field shift of the $\mathrm{C}=\mathrm{N}$ stretch of ligand $\mathbf{L}^{2}$ on the formation of compound 3 .

Structures of compounds 1-3. The molecular structure of compound $\mathbf{1}$ with the atom-numbering scheme is given in Figure 1. The Rh metal can be described to have an octahedral coordination sphere, if the coordination number of the $\mathrm{Cp}^{*}$ ring is taken to be three. Ligand $\mathbf{L}^{1}$ is $N$-coordinated to the Rh metal. Two terminal thiophene rings are oriented in the exo direction to avoid the steric congestion due to the presence of the $\mathrm{Cp}$ * ring. The bond angles around two imine nitrogen atoms are significantly different: C15-N1-N2 $=106.8(4)$; N1-N2$\mathrm{C} 16=113.5(4)^{\mathrm{O}}$.

Figure 2 shows the structure of the cationic part of compound $\mathbf{2} \cdot \mathrm{CH}_{2} \mathrm{Cl}_{2}$. Like compound $\mathbf{1}$, compound $\mathbf{2}$ has a cisoid conformation of two thiophene rings, with the $\mathrm{S} \cdots \mathrm{S}$ separation of 3.719(2) $(\AA)$. Ligand $\mathbf{L}^{1}$ in compound $\mathbf{2}$ occupies the site that the OTf ligand occupied in the starting compound.

The local coordination environment of $\mathrm{Rh}$ in compound $\mathbf{3}$ is shown in Figure 3. An asymmetric unit consists of one Rh, one ligand $\mathbf{L}^{\mathbf{2}}$, and one OTf ion. The Rh metal is coordinated to two $\mathrm{N}$ atoms of two $\mathbf{L}^{2}$ ligands and therefore can be described as 2-coordinate. In addition to the two normal covalent Rh1-N bonds, the Rh1 metal is further bound to four $\mathrm{O}$ atoms $(\mathrm{O} 1, \mathrm{O} 2$, $\mathrm{O} 3$, and O5A) via van der Waals contacts $(\mathrm{Rh} \cdots \mathrm{O}=2.527(4)$ -

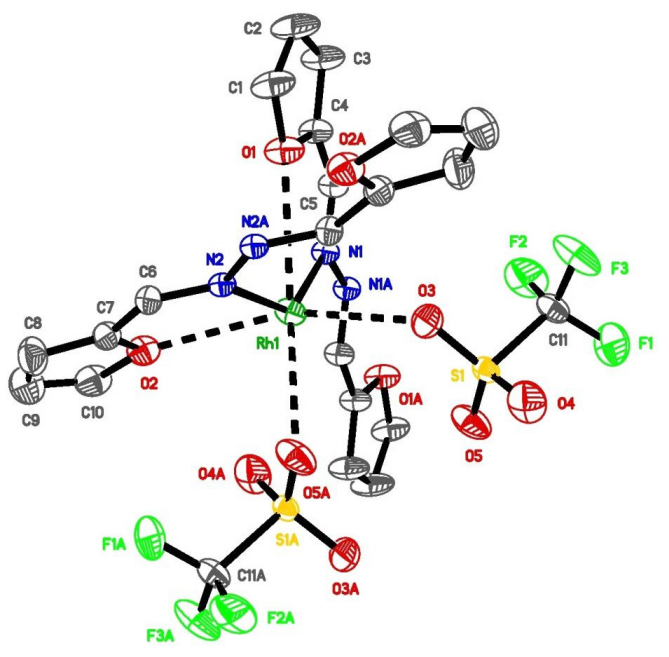

Figure 3. ORTEP drawing of compound 3.

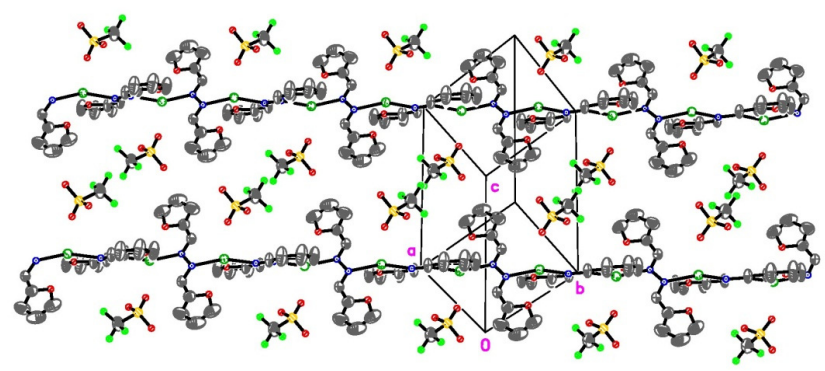

Figure 4. Packing diagram of compound 3, in which van der Waals contacts are not represented for clarity.

2.887(3) Å). Considering the Rh-N covalent bonds and $\mathrm{Rh} \cdots \mathrm{O}$ van der Waals contacts together, the coordination sphere of Rh can be best described as a distorted octahedron. For comparison, the van der Waals radii of $\mathrm{Rh}$ and $\mathrm{O}$ are 2.00 and $1.52 \AA$, respectively. Two ligands around the Rh metal are oriented roughly perpendicular to each other with the dihedral angle of $62.7(2)^{\circ}$ between the furan rings (ring 1: O1, C1-C4; ring 2: O3, C7-C10). The packing diagram of polymer $\mathbf{1}$ is presented in Figure 4, which clearly demonstrates a 1-dimensional structure. The $\mathbf{L}^{2}$ ligands link the $\mathrm{Rh}$ metals approximately in the direction [110] to form a linear 1-D chain, in which the OTf ions are located near the Rh metals via van der Waals contacts. Rhodium coordination polymers constructed by bis(pyridine)-type linking ligands are quite rare. To our best knowledge, only Maekawa's group reported such polymers, which are 1-D zigzag chains: (1) $\left\{[\mathrm{Rh}(4-\mathrm{bpbd})(\mathrm{cod})] \cdot\left(\mathrm{BF}_{4}\right)\right\}_{\infty}(4-\mathrm{bpbd}=1$,4-bis(4-pyridyl)butadiyne; cod = cycloocta-1,5-diene $),(2)\{[\mathrm{Rh}(4-\mathrm{bpbd})(\mathrm{cod})]$. $\left.\left(\mathrm{PF}_{6}\right)\right\}_{\infty}$, and (3) $\left\{[\mathrm{Rh}(4-\mathrm{bpe})(\mathrm{cod})] \cdot\left(\mathrm{BF}_{4}\right)\right\}_{\infty}(4-\mathrm{bpe}=$ trans $-1,2-$ bis(4-pyridyl)ethylene (4-bpe). ${ }^{27}$

In summary, we investigated the reactivity of the $\mathrm{Rh}-\mathrm{Cp}^{*}$ complexes containing labile ligands, $\left[\mathrm{Cp} * \mathrm{RhCl}_{2}\right]_{2}$, $[\mathrm{Cp} * \mathrm{Rh}$ $\left.\left(\eta^{2}-\mathrm{NO}_{3}\right)(\mathrm{OTf})\right]$, and $\left[\mathrm{Cp} * \mathrm{Rh}\left(\mathrm{OH}_{2}\right)_{3}\right](\mathrm{OTf})_{2}$, toward potential linking ligands $\left[\mathbf{L}^{1}=\right.$ (2-thiophene)- $\mathrm{CH}=\mathrm{N}-\mathrm{N}=\mathrm{CH}$-(2-thiophene); $\mathbf{L}^{2}=$ (2-furan)- $\mathrm{CH}=\mathrm{N}-\mathrm{N}=\mathrm{CH}-(2$-furan $\left.)\right]$. From these reactions, two molecular species, $\left[\mathrm{Cp} * \mathrm{Rh}\left(\mathbf{L}^{1}\right) \mathrm{Cl}_{2}\right](\mathbf{1})$ and $\left[\mathrm{Cp}^{*}\right.$ 
$\left.\mathrm{Rh}\left(\eta^{2}-\mathrm{NO}_{3}\right)\left(\mathbf{L}^{\mathbf{1}}\right)\right](\mathrm{OTf}) \cdot \mathrm{CH}_{2} \mathrm{Cl}_{2}\left(\mathbf{2} \cdot \mathrm{CH}_{2} \mathrm{Cl}_{2}\right)$, and one rhodium coordination polymer, $\left\{\left[\mathrm{Rh}\left(\mathbf{L}^{2}\right)\right] \cdot(\mathrm{OTf})\right\}_{\infty}(\mathbf{3})$, were produced. In all three compounds, the central imine nitrogen atoms coordinate to the $\mathrm{Rh}$ metal. The structure of compound $\mathbf{2}$ indicates the higher lability of the OTf ligand compared with that of the $\mathrm{NO}_{3}{ }^{-}$ligand. The structures of compounds 1-3 strongly suggest that the $\mathrm{Rh}$ (III) in the starting compounds are rather harder than expected, probably due to its relatively high formal oxidation number $(+3)$. We will explore the reactions of low-oxidationstate $\mathrm{Rh}(0$ or +1$)$ complexes with ligands $\mathbf{L}^{\mathbf{1}}$ and $\mathbf{L}^{\mathbf{2}}$ to obtain other rhodium coordination polymers.

Acknowledgments. This work was supported by Mid-career Researcher Program through the National Research Foundation of Korea (NRF) funded by the Ministry of Education, Science, and Technology (No. 2009-0079916).

\section{References}

1. Leininger, S.; Olenyuk, B.; Stang, P. J. Chem. Rev. 2000, 100, 853.

2. Swiegers, G. F.; Malefetse, T. J. Chem. Rev. 2000, 100, 3483.

3. Sun, S.-S.; Lees, A. J. Coord. Chem. Rev. 2002, $230,171$.

4. Swiegers, G. F.; Malefetse, T. J. Coord. Chem. Rev. 2002, 225, 91.

5. Brunner, H.; Janietz, N.; Meier, W.; Wachter, J.; Herdtweck, E.; Herrmann, W. A.; Serhadli, O.; Ziegler, M. L. J. Organomet. Chem. 1988, 347, 237.

6. Contakes, S. M.; Klausmeyer, K. K.; Milberg, R. M.; Wilson, S. R.; Rauchfuss, T. B. Organometallics 1998, 17, 3633.

7. Klausmeyer, K. K.; Rauchfuss, T. B.; Wilson, S. R. Angew. Chem. Int. Ed. 1998, 37, 1694.
8. Klausmeyer, K. K.; Wilson, S. R.; Rauchfuss, T. B. J. Am. Chem. Soc. 1999, 121, 2705.

9. Suzuki, H.; Tajima, N.; Tatsumi, K.; Yamamoto, Y. Chem. Commun. 2000, 1081.

10. Cotton, F. A.; Lin, C.; Murillo, C. A. Acc. Chem. Res. 2001, 34, 759.

11. Yamamoto, Y.; Nakamura, H.; Ma, J.-F. J. Organomet. Chem. 2001, 640, 10.

12. Bera, J. K.; Campos-Fernández, C. S.; Rodolphe, C.; Dunbar, K. R. Chem. Commun. 2002, 2536.

13. Angaridis, P.; Berry, J. F.; Cotton, F. A.; Murillo, C. A.; Wang, X. J. Am. Chem. Soc. 2003, 125, 10327.

14. Seino, H.; Masumori, T.; Hidai, M.; Mizobe, Y. Organometallics 2003, 23, 3424.

15. Wang, J.-Q.; Ren, C.-X.; Jin, G.-X. Organometallics 2005, $25,74$.

16. Lim, M. S.; Baeg, J. Y.; Lee, S. W. J. Organomet. Chem. 2006, $691,4100$.

17. Han, W. S.; Lee, S. W. Dalton Trans. 2004, 1656.

18. Han, W. S.; Lee, S. W. Dalton Trans. 2004, 3360.

19. Han, W. S.; Lee, S. W. J. Organomet. Chem. 2003, 678, 102.

20. Kang, J. W.; Moseley, K.; Maitlis, P. M. J. Am. Chem. Soc. 1969, $91,5970$.

21. Han, W. S.; Lee, S. W. Inorg. Chim. Acta 2003, 348, 15.

22. Espinet, P.; Bailey, P. M.; Downey, R. F.; Maitlis, P. M. J. Chem. Soc., Dalton Trans. 1980, 1048.

23. Lee, H. K.; Lee, S. W. Bull. Korean Chem. Soc. 2007, 28, 421.

24. Lee, H. K.; Lee, S. W. J. Korean Chem. Soc. 2006, 50, 420.

25. Sheldrick, G. M. SADABS, Program for Absorption Correction, University of Göttingen, 1996.

26. Bruker, SHELXTL, Structure Determination Software Programs, Bruker Analytical X-ray Instruments Inc., Madison, Wisconsin, USA, 1997.

27. Maekawa, M.; Sugimoto, K.; Kuroda-Sowa, T.; Suenaga, Y.; Munakata; M. J. Chem. Soc., Dalton Trans. 1999, 4357. 